\title{
ORIGINAL PAPER \\ Is economic history changing its nature? Evidence from top journals
}

\author{
Martina Cioni ${ }^{1} \cdot$ Giovanni Federico $^{2,4} \cdot$ Michelangelo Vasta $^{3,4}$ (i)
}

Received: 26 September 2021 / Accepted: 1 January 2022 / Published online: 4 February 2022

(c) The Author(s) 2022

\begin{abstract}
A recent stream of literature argues that economic history is expanding its aim of looking for the historical roots of current outcomes (persistence studies) and that it is increasingly integrating with economics. This paper tests these claims with a new database of about 2500 articles published from 2001 to 2018 in the top five economic history journals and in eight leading economics journals. Our results do not confirm this optimistic narrative. Despite a growing interest by economists, economic history and a fortiori persistence studies are still marginal in economics journals. Furthermore, substantial differences between articles in the two groups of outlets are visible. Only a few authors have published in both economics and economic history journals. Publishing in the top five economics journals yields more citations than in top-field journals, but this is not necessarily true for other prestigious economics journals.
\end{abstract}

Keywords Bibliometric analysis · Citations $\cdot$ Economic history $\cdot$ Economics journals

JEL Classification A12 · N01

Michelangelo Vasta

vasta@unisi.it

Martina Cioni

martina.cioni@unisi.it

Giovanni Federico

gf63@nyu.edu

1 Department of Economics and Statistics, University of Siena, Siena, Italy

2 Division of Social Sciences, NYUAD, Abu Dhabi, United Arab Emirates

3 Department of Economics and Statistics, University of Siena, Siena, Italy

4 CEPR, London, United Kingdom 


\section{Introduction}

Economic history is allegedly back in fashion among economists. In a recent article in one of the most important scientific journals (Science), Nunn (2020: 1441) notes: 'In recent decades, there has been a rapidly growing body of research within economics [our italics] that takes a historical perspective when attempting to understand contemporary issues related to global poverty and comparative development'. Other scholars hail the 'integration of economic history into economics', quoting as main evidence the growing number of economic history articles in economics journals, particularly in the top five (Abramitzky 2015; Margo 2018; Diebolt and Haupert 2019a; Jaremski 2020). Young economic historians are trained as economists and increasingly imitate their $\mathrm{PhD}$ colleagues in their publication strategy, both in the choice of journals and in the use of modern economics jargon ('quasi-natural experiments' and so on) and of advanced econometrics. In contrast, Cantoni and Yutchman (2021), in their recent survey on 'natural experiments' in economic history, express some doubts about the excessive reliance on a simple identification strategy and on the 'very narrow historical analysis' of this approach.

This paper extends this latter view to the wider field of economic history, providing a systematic quantitative analysis of economic history articles in leading economics journals and in top field journals. Our results suggest a somewhat less upbeat view of the state of the art of economic history. As a preliminary point, it is important to stress that Nunn's 'changing nature' and the 'integration' claim refer to two quite different research agendas. Cantoni and Yutchman (2021) distinguish '[natural] experiments to understand contemporary outcomes' from 'experiments to understand history', which is the traditional aim of economic history. They also introduce a third residual category-'experiments to understand economics'which uses historical data to test models or to estimate parameters of interest for other economics subfields (e.g. labour economics, public finance and political economy). Nunn (2020) refers to the first category, often labelled 'persistence studies' (henceforth PS for the sake of brevity). This novel approach was pioneered in 2001 by Acemoglu et al. (2001) in a highly successful article that traced the impact of past colonial institutions on GDP per capita in 1995. This was the 'tipping point' (Michalopoulos and Papaioannou 2017) of the development of a robust and lively literature that investigates present-day outcomes as the effects of permanent features or of specific events that happened many decades or several centuries earlier (Cioni Federico and Vasta 2021a, 2021b). As we will show in Sect. 3, 'persistence studies' still account for a fairly small share of the total economic history literature. They hardly feature in top economic history journals and are a minority of economic history articles in economics journals. Most of the latter still belong to the second category in the taxonomy by Cantoni and Yuchtman (2021) of 'traditional' economic history.

Economic history was an integral part of economics training until the mathematisation of economics in the post-WWII period (Debreu 1991). This caused a methodological divergence between mainstream economics and economic history, which lasted until the spread of the so-called Cliometrics Revolution of the 1960s (Cioni 
et al. 2021a). Cliometricians were trained as economists, used economic reasoning and, when possible, econometrics to obtain the historically relevant results. They also tried to speak to historians: Sutch (1991), in his presidential address to the Economic History Association, called this the 'third task' of the Association after having successfully shown that economics is relevant for writing good economic history and that economic history is relevant for 'writing and teaching of good economic theory'. However, the hope of convincing historians of the virtues of (Cliometric) economic history largely failed, and it has remained a subfield of economics. As such, its practitioners, especially in the USA, have been following the general trends in the profession, including the 'credibility revolution' (Angrist and Pischke 2010) and, above all, the recent obsession with publishing in the top five economics journals (Heckman and Moktan 2020). These trends might open a cleavage within economic history, as publishing in top economics journals may require a distinctive approach (e.g. selecting topics of interest to economists, introducing a research question strictly connected with economic theory and providing extensive robustness checks).

This paper tests the existence of this cleavage and verifies whether publishing in economics journals gives more citational success relative to publish in top field journals, which are arguably more representative of the (Cliometric) profession at large. To this aim, we compare the 365 articles on economic history issues ("persistence studies' included) in eight leading economics journals with the 2153 articles in the top five field journals. We find sizeable differences in articles and authorship. Unsurprisingly, articles in the top five economics journals are cited much more than articles in top field journals, but the gap with other major economics journals is smaller and disappears if one considers only a comparably sized sample of the most successful articles in economic history journals. It would be interesting to know whether and to what extent this difference between articles in general-interest journals and in top field journals is common to other heavily empirical fields, such as labour economics. However, this would imply a different research question that focuses on segmentation within economics rather than on the state of the art in economic history.

The rest of the paper is organized as follows. We start with a short outline of the evolution of the discipline and of the literature on 'integration' (Sect. 2), and we continue with a detailed description of our database (Sect. 3). In the following two sections, we focus on the issue of the 'integration' of economic history into economics by looking at the share of economic history articles in top economics journals (Sect. 4) and at the differences between economics and economic history journals in the type of articles, affiliations of authors and pattern of citations (Sect. 5). In Sect. 6, we measure the success of economic history articles in different categories of journals, as proxied by the number of citations per year they have received. Section 7 concludes. 


\section{The evolution of economic history}

The Cliometric Revolution started in 1958 with an article by two economists on the efficiency of American slavery in the Journal of Political Economy (Conrad and Meyer 1958). They were followed by several young scholars with economics training who approached big issues in American economic history with then stateof-the-art economics and econometrics (Andreano 1970; Lyons et al. 2007; Greasley and Oxley 2010; Diebolt and Haupert 2021). ${ }^{1}$ Douglass North and Robert Fogel obtained new and provocative results, which attracted much interest among economists and earned them the Nobel Prize in 1993. In the 1960s and 1970s, this 'new' economic history, later relabelled Cliometric history, became the dominant approach in the USA and Canada, against strong opposition from 'traditional' economic historians (Diebolt and Haupert 2019a). By the 1980s Cliometrics had diffused throughout the UK, and since the 1990s, it has spread widely in continental Europe and made some inroads in the rest of the world (Cioni et al. 2020). Its expansion was not only geographic but also temporal, reaching back in time to the Middle Ages. However, after the initial enthusiasm, its appeal faded fast (McCloskey 1976). Parker (1986) and more recently Demeulemeester and Diebolt (2007), in the first presentation of this journal, argued that the empirical nature of economic history could offer many insights for economists, although American economists of the 1980s and 1990s were not so impressed. Perhaps they were not as excited by works on European or world economic history as they had been by the original core Cliometrics results on American history (Diebolt and Haupert 2021). They increasingly came to regard economic history as a highly specialised subject, which could easily be dropped from economists' training. To date, approximately half of $\mathrm{PhD}$ programs have no economic history course, and only a very few include it in their core requirements (Diebolt and Haupert 2019b). The syllabi of the remaining courses focus on a few big issues and on empirical techniques of data collection and handling rather than on economic history (Jaremski 2020). The strong reduction in positions for teaching economic history has pushed young economic historians to market themselves (also or sometimes exclusively) as specialists of other fields (Diebolt and Haupert 2021). Thus, newly minted PhD students from top economics departments with a dissertation on economic history have, at least in the USA, the same chances of recruitment as their colleagues with a dissertation in economics.

There is no doubt that the winds are changing, with economic history, including the more 'traditional' Cliometric literature, attracting more attention from economists. ${ }^{2}$ Several survey articles have stressed the relevance of history in understanding economic changes (Nunn 2009; Spolaore and Wacziarg 2013; Ashraf and Galor

\footnotetext{
1 As an example, Richard Sutch earned his PhD at the Massachusetts Institute of Technology (MIT) with a thesis on economic theory (Expectations, Risk, and the Term Structure of Interest Rates) under the supervision of Franco Modigliani.

2 In recent times, historians have also shown a renewed interest in economic issues, under the generic label of 'history of capitalism'. We do not cover this literature, which harks back to the pre-Cliometric tradition. For a survey of some recent books, see Hilt (2017).
} 
2018), and two recent books have offered up-to-date views of the field from different perspectives. The Handbook of Cliometrics (Diebolt and Haupert 2019c) surveys the results of the economic history literature, while the Handbook of Historical Economics (Bisin and Federico 2021a) focuses on the opportunities and challenges of the interaction between economic history and economics. The range of issues economists are interested in has drastically widened towards social developments, politics and so on, and the movement has also affected historical works (Cioni et al. 2021a). However, 'persistence studies' have attracted most of the attention.

In the evocative words of Michalopoulos and Papaioannou (2017), 'persistence studies' look for 'the shadow that history casts over the present', and thus, they resonate with economists' prevailing interest in the present, which contrasts with the interest in history for its own sake by economic historians (Abramitzky 2015). 'Persistence studies' have also been the subject of criticism. Austin (2008) has strongly criticised the 'compression of history', while others have raised doubts about the reliability of the data (Albouy 2012; Acemoglu et al. 2012) and the assumptions underlying the econometric techniques (Arroyo Abad and Maurer 2021, Dippel and Leonard 2021). In two distinct papers, Kelly $(2019,2020)$ suggested that the results of 'persistence studies' might be spuriously improved by (not controlled for) spatial autocorrelation and by a lack of (simple) controls. In a more general vein, Voth (2021) points out that only a minority of studies ('apples-on-apples') focus on the persistence of a specific feature (e.g. a cultural belief). Most works ('apples-andoranges') relate past events and current outcomes that are inherently different, such as the diffusion of tze-tze flies, precolonial institutions and levels of development in Africa as proxied by the current luminosity (Alsan 2015). Only a (growing) minority of 'persistence studies' ('apples and oranges with theory') buttress the inferences with some theoretical reasoning about causal mechanisms. The use of statistical inference as the main (or unique) standard of proof may yield 'very narrow historical analysis once a (seemingly) clean source of historical variation is identified' (Cantoni and Yuchtman 2021: 233). Economists should remember that, as a now almost forgotten economic historian once wrote, 'Clio is a messy housewife' (Gerschenkron 1962).

\section{Data}

Our database includes all articles published in the top five economic history journals (henceforth T-ec.hist), in the top five economics journals and in three other major generalist economics journals (henceforth 'other economics journals') from 2001 to 2018 (henceforth we indicate as T8 the set of eight economics journals). As universally agreed (Heckman and Moktan 2020), the top five are the American Economic Review (AER), Econometrica (ECMA), the Journal of Political Economy (JPE), the Quarterly Journal of Economics (QJE), and the Review of Economic Studies (RESTUD). ${ }^{3}$ T-ec.hist were defined in Cioni et al. (2020) as Cliometrica (CLIO),

\footnotetext{
${ }_{3}$ For an analysis of recent trends in the top five economics journals, see Wei (2019).
} 
Explorations in Economic History (EEH), the Economic History Review (EHR), the European Review of Economic History (EREH) and the Journal of Economic History $(J E H)$. We selected the 'other economics journals'-Economic Journal (EJ), the Journal of Economic Literature (JEL) and the Review of Economics and Statistics (RESTAT) — according to three criteria: (1) they must be, as the AER defines itself, 'general-interest economics journal', i.e. they accept articles on all issues in economics rather than on a specific set of topics ${ }^{4}$; (2) they started publications before 2001; and (3) they are highly ranked, i.e. they are classified, on average, above the 15th position in a set of ten recent rankings of economics journals, based on Bornmann et al. (2018) (see Appendix: Table A1). ${ }^{5}$ These criteria exclude some highly reputed general-interest journals, such as the American Economic Journal (established in 2009), the Journal of European Economic Association (established in 2003) and all field journals; however, they are high in rankings (for instance, the Journal of Finance and Journal of Econometrics). ${ }^{6}$

We have selected articles on economic history issues in economics journals by looking at their abstracts and/or content and, when available, at the JEL codes ( $\mathrm{N}$ category-Economic History) of the American Economic Association (AEA). ${ }^{7}$ Our initial selection was as comprehensive as possible, including all articles that explore any type of relation between events, institutions and behaviours (and their changes) in the past and their economic outcomes in either the past or the present. However, following standard practice in the literature (Abramitzky 2015; Hamermesh 2018; Heckman and Moktan 2020), we have omitted nonresearch articles (short notes, comments, replays, rejoinders, rebuttals and essays in bibliography) from the sample in the T-ec.hist; neither have we considered economic history articles published in the AER's annual issue of Papers and Proceedings. ${ }^{8}$ These articles are usually very short and have few references; thus, their inclusion would bias the citation analysis.

\footnotetext{
${ }^{4}$ For instance, the $E J$, as claimed on its website, provides "a platform for high-quality, imaginative economic research, earning a worldwide reputation for excellence as a general interest journal, publishing papers in all fields of economics for a broad international readership".

5 We have selected the seven most recent rankings quoted by Bornmann, Butz and Wohlrabe (2018), their own ranking, and we add the rankings by Heckman and Moktan (2020) and the 'Aggregate ranking all years' from REPEC (accessed September 2020). The average ranking is 8.2th for the JEL (with positions ranging from 1 st to 28 th), 9.7 th for RESTAT (from 7 to 12 th) and 14.5 th for EJ (from 7 th to $27 \mathrm{nd}$ ).

6 We exclude the Journal of Economic Perspective but not the JEL because they target a different readership, as stated in the $A E R$ website. The former "attempts to fill a gap between the general interest press and most other academic economics journals", while the latter "is designed to help economists keep abreast of and synthesise the vast flow of literature". Moreover, the Journal of Economic Perspective, unlike the $J E L$, is upon invitation only. In the working paper version of the article (Cioni, Federico and Vasta 2021c), we extend the analysis to five additional major economics journals: the Journal of Development Economics, the Journal of Economic Growth, the Journal of Economic Theory, the Journal of Monetary economics, and the Journal of Public Economics.

7 We do not rely exclusively on JEL codes because they are missing in some journals and for some periods and are not always consistent between the journal website and the printed (or pdf) version. Furthermore, the JEL codes can be misleading, as pointed out by Abramitzky (2015: 1242), who uses them for selecting economic history articles in the top five journals. The $\mathrm{N}$ code can be missing in some economic history articles and present in others, which do not deal primarily with economic history issues.

8 The special status of the Papers and Proceedings is further shown by the decision of the AEA to split them as a standalone journal since 2018 .
} 
We distinguish articles in economics journals between 'traditional economic history' or 'persistence studies': the latter are defined as all articles that explain one or more outcomes in the main regression as the consequences of specific past events, at least a century earlier than the outcome(s). All other articles are classified as 'traditional economic history'. An example of these latter works is the one by Squicciarini and Voigtländer (2015), which estimates the contribution to economic growth, proxied by city growth, of upper-tail human capital (as measured by subscriptions to the Encyclopédie in the late eighteenth century) via the diffusion of modern technologies in nineteenth-century France.

Our database includes a total of 2518 articles, 2153 articles in T-ec.hist and 365 economic history articles (i.e. 'traditional economic history' and 'persistence studies') in economics journals (Table 1).

As a second step, we classified all articles in the database according to topic, historical period, geographical area and econometric techniques by looking at the title, abstract and, whenever necessary, text.

(1) We first distribute topics in 17 categories (see Appendix: Table A2), and then, for estimation purposes, we aggregate them into five groups: 'methodology' (inclusive of articles on the history of economic thought), 'institutions', 'macro approach' (dealing with growth, economic policies, and trade), 'micro approach' (finance, firms and innovation) and 'personal conditions and behaviour' (inequality, human capital, population and demography).

(2) We follow the standard division between 'classical and medieval history' (before 1492 ) and 'early modern history' (1492-1815), but, given their large number, we split the articles on 'modern history' (1815-present) into the 'long nineteenth century' (1815-1914) and the 'twentieth century' (1915-present). ${ }^{9}$ We label as 'long-run' those articles covering at least two hundred years and straddling at least two periods and as 'no period' those articles on methodology and on the history of economic thought, which do not refer to a specific period.

(3) We distinguish articles by geographical area of interest between 'single-country' (e.g. the UK and the USA) and 'cross-country', with a residual 'no area' category for articles on methodology and the history of economic thought.

(4) We classify econometric techniques as 'basic' (e.g. coefficient of correlation and OLS regressions) or 'advanced' (e.g. differences-in-differences, instrumental variables, panel regressions, propensity score matching, vector-autoregression or VAR and vector error correction model or VECM).

For each article, we retrieved information on the author(s), including name, gender and institutional affiliation at the time of publication as stated in the article, as well as on the number of citations received as reported in the Scopus database

\footnotetext{
${ }^{9}$ We allocate articles dealing with two or more periods but covering less than 200 years, to the period which covers the higher number of years.
} 
between 13 and 18 May 2019. We preferred Scopus to Journal of Citations Report because it offers wider coverage of journals and a simpler method for retrieving data. ${ }^{10}$ By then, T-ec.hist had received 29,679 citations, while the economic history articles in T8 had amassed 33,762 citations (24,596 in the top five and 9166 in the 'other economics journals'). Finally, we retrieved all the references contained in the bibliography of each article for a total of 146,950 references - that is, an average of nearly 60 references per article.

\section{Economic history articles in economics journals: a first look at the data}

As a starting point, Fig. 1 plots the share of economic history articles in the top five, in the 'other economics journals' and in the sum of these two groups for the period 1975-2018.

Overall, the data downplay the extent of the recent integration of economic history into economics. To be sure, the share of economic history articles is significantly higher after $2001(5.2 \%)$ than in the last quarter of the twentieth century (3.4\%), and the increase is even larger for the top five (from 2.1 in 1975-2000 to $3.6 \%$ in 2001-2018). ${ }^{11}$ On the other hand, the last quarter of the twentieth century was a difficult age for economic history in economics journals, which contrasts with the high status of the discipline before WWII. From 1925 to 1945, economic history articles accounted for $6.7 \%$ of articles in $A E R, Q J E$ and $J P E$, and the share remained marginally higher in 1945-1974 (3.8\%) than in 1975-2000 (McCloskey 1976). ${ }^{12}$ From 1975 to 1989 , the top five published a total of 96 articles in economic history (1.9\% of the total), and 25 of them (i.e. one-quarter) were published in only two years, 1984 and 1986. In quite a few years of that period, the top five published five or fewer economic history articles out of about 350. The situation started to improve in the 1990s when the top five published a total of 66 economic history articles (2.5\% of all articles), and the share remained roughly constant throughout the twenty-first century, without any clear upwards trend. ${ }^{13}$ The overall share fluctuated widely at approximately $4 \%$ and was decidedly higher for the 'other economics journals' (5.0\% or 9.3 articles per year) than for the top five (3.6\% or 11 per year). Figure 2 adds two important pieces of information.

\footnotetext{
10 Anauati et al. (2016) in a paper on the life cycle of articles in the top five economics journals use Google Scholar rather than Scopus as the source, but the number of citations is strongly correlated.

11 This trend is confirmed by the analysis of Card and DellaVigna (2013: Table A5) based on the JEL codes in the Econlit database.

12 McCloskey does not consider ECMA and RESTUD, which started to be published in the 1930s. In line with our estimates, the data by Angrist et al. (2020: Table 2) show that economic history articles account for $2.9 \%$ of all articles published from 1970 to 2015 in a database of about 140,000 articles published in 50 leading economics journals.

13 This view is confirmed by looking at a large set of journals since 2001 (Cioni et al. 2021c: Fig. 2 and Table A4 in the Appendix).
} 
Table 1 Number of articles in the database (2001-2018)

\begin{tabular}{llll}
\hline Journal & $\begin{array}{l}\text { Traditional eco- } \\
\text { nomic history }\end{array}$ & $\begin{array}{l}\text { Persistence } \\
\text { studies }\end{array}$ & Total \\
\hline CLIO & 161 & & 161 \\
EEH & 491 & & 491 \\
EHR & 617 & & 617 \\
EREH & 307 & & 307 \\
JEH & 577 & & 577 \\
T-ec.hist & $\mathbf{2 1 5 3}$ & & $\mathbf{2 1 5 3}$ \\
AER & 87 & 9 & 96 \\
ECMA & 5 & 4 & 9 \\
JPE & 27 & - & 27 \\
QJE & 53 & 8 & 61 \\
RESTUD & 5 & - & 5 \\
Top five & $\mathbf{1 7 7}$ & $\mathbf{2 1}$ & $\mathbf{1 9 8}$ \\
EJ & 68 & 9 & 77 \\
JEL & 15 & 1 & 16 \\
RESTAT & 65 & 9 & 74 \\
Other economics journals & $\mathbf{1 4 8}$ & $\mathbf{1 9}$ & $\mathbf{1 6 7}$ \\
T8 & $\mathbf{3 2 5}$ & $\mathbf{4 0}$ & $\mathbf{3 6 5}$ \\
Total & $\mathbf{2 4 7 8}$ & $\mathbf{4 0}$ & $\mathbf{2 5 1 8}$ \\
\hline & & & \\
\hline
\end{tabular}

Bold values indicates sub-total and total number of articles by group of journals

Our own elaborations

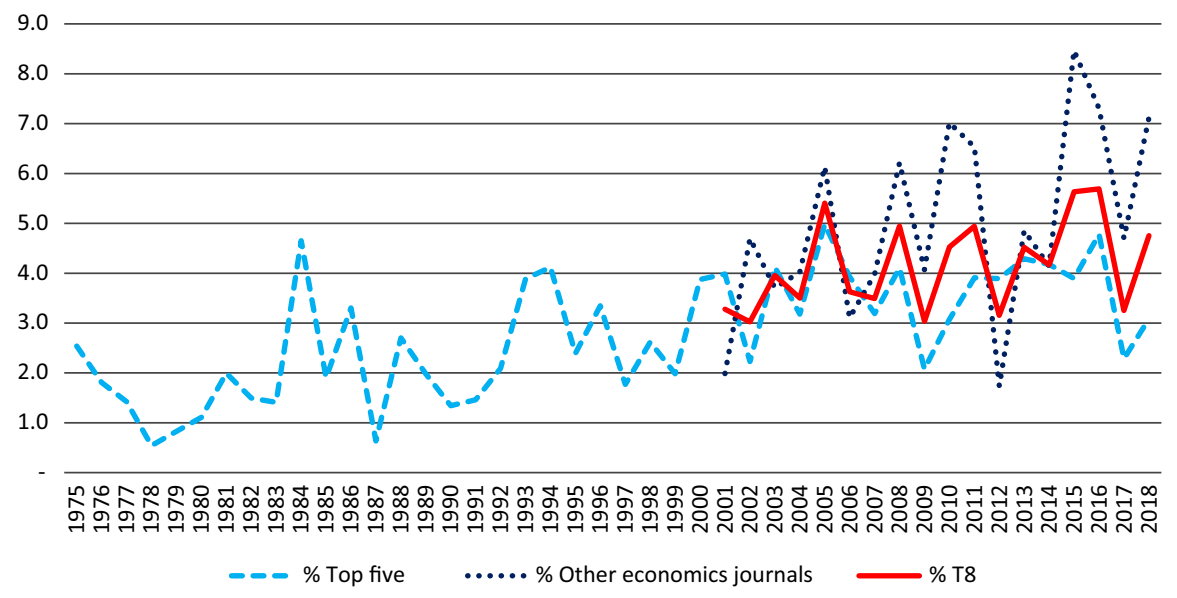

Fig. 1 Share of economic history articles by different groups of journals (1975-2018). Source: for economic history articles, 1975-2000, Abramitzky (2015); 2001-2018 our own data; for universe: 19752000, Card and DellaVigna (2013, Appendix); 2001-2018 our own data 


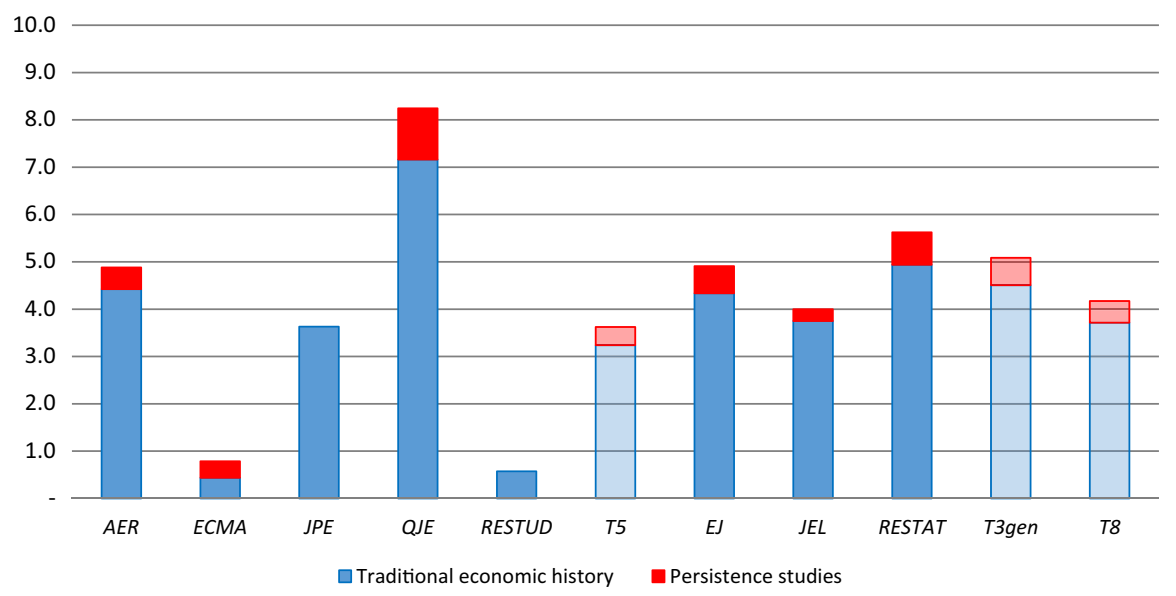

Fig. 2 Share of economic history articles in the T8 (2001-2018). Source: our own elaborations

First, there are substantial differences among T8, with shares ranging from $8 \%$ in the QJE to less than $1 \%$ for ECMA and RESTUD. Second, until 2018, "persistence studies' (the red parts of the bars in Fig. 2) were a niche approach in T8, accounting for about one-ninth of all 'core' articles (i.e. for $0.5 \%$ of the total) and exceeding $1 \%$ of the total only in $Q J E$. About four-fifths of all 'persistence studies' in our database were published after 2010, and yet in those years, they accounted for approximately one-seventh of all history articles and $0.7 \%$ of all articles in the T8. As with any radically new approach, 'persistence studies' probably require time to develop, and indeed, the field is still growing quite quickly. However, the recent survey by Michalopoulous and Papaioannu (2020) quotes several working papers and unpublished articles that adopt this new approach.

\section{Economic history: a deeply divided field}

We explore the divide within economic history by looking at three dimensions. First, we measure differences in four key features (topic, period, geographical area of interest and use of econometric techniques) between articles in T-ec.hist and in T8, further distinguishing between the top five and the 'other economics journals'. Then, we explore the publication strategies and affiliation of the authors, and finally, we analyse the pattern of cross-citations-i.e. the number of citations of T-ec.hist in the T8 and vice versa.

5.1 The differences between articles in economics and economic history journals are substantial in all four features we take into account. ${ }^{14}$ As an example, let us consider topics. The category 'institutions' accounts for most articles in both economics

${ }^{14} \mathrm{Cf}$. Table A3a in the Appendix for topics, A3b for historical period, A3c for geographical area and A3d for the use of econometrics. 
and economic history journals, but its share is approximately half higher in the former than in the latter (20.0 vs. $13.1 \%)$. Institutions are a very diversified category, which in economics journals include quite a few articles on political science issues, such as the roots of the electoral success of the Nazi party (Adena et al. 2015; Satyanath et al. 2017). However, differences are also wide in more narrowly defined categories: in T8 $10.4 \%$ of the articles deal with population and demography issues, and $6.6 \%$ deal with standard of living, while the proportions are almost reversed in T-ec.hist journals (4.9\% and $11.8 \%$, respectively). ${ }^{15}$ On the other hand, the differences are less clear-cut for other topics, such as labour or innovation.

We estimate these differences more precisely by running a set of multinomial logistic regressions, following Hamermesh (2013) for the whole period (Table 2, 3, 4, 5), and separately for 2001-2009 and 2010-2018 (Tables A4 and A5 in Appendix). The dependent variable is the number of articles for each category, and the reference category is T-ec.hist: a significant coefficient signals a difference with either the top five or 'other economics journals'. A positive (negative) sign implies that the group of articles as defined in the top row is more (less) frequent than the baseline outcome, i.e. 'institutions' for topics (Table 2), 'long nineteenth century (1815-1914)' for historical periods (Table 3), 'United Kingdom' for geographical areas (Table 4) and 'no econometrics' for the techniques (Table 5).

The exercise confirms that differences between T-ec.hist and T8 are quite wide but also identifies relevant differences between the top five and 'other economics journals'. Almost three-quarters of all coefficients (20 out of 28) are significant, and most of them are significant at $1 \%$. Table 2 shows that economics journals have published more articles on 'institutions' than economic history journals. The gap is quite wide for the top five in both periods, while it opened in the 'other economics journals' only in 2010-2018 (Table A5 in Appendix). Indeed, articles on 'institutions' in 2010-2018 account only for $11.7 \%$ in the T-ec.hist and for $28 \%$ in the top five, while the share for the 'other economics journals' increases considerably from 4.7 in $2001-2009$ to $19.4 \%$ in $2010-2018$. Other features do not change over time. T8 published more articles in the 'long run' and on the 'twentieth century' than T-ec.hist (Table 3). The high share of articles on the twentieth century in the T8 reflects the greater interest among economists for events closer in time, but in all likelihood, also is a reflection of the abundance of data which make it possible to use advanced econometric techniques (Table 5). The share of articles in the USA is significantly higher in economics journals than in economic history journals (Table 4) due to the abundance of data, possibly the location of journals and above all for the high share of American-affiliated authors, jointly with home bias, i.e. the generalised tendency of authors to write about their own country (Cioni et al. 2020). However, the coefficients for 'cross country', 'Continental Europe' and 'rest of the world' are also positive and, in most cases, significant. This reflects the somewhat skewed distribution by area of articles in the reference category, the T-ec.hist: about

\footnotetext{
15 The largest differences appear in marginal categories with very few articles such as history of economic thought (13 articles in the T8, i.e., $3.6 \%$ vs. $10-0.5 \%$ in T-ec.hist) and firm (1 vs. 38 articles).
} 
Table 2 Multinomial logit estimates: topics (2001-2018)

\begin{tabular}{llllll}
\hline Variables & Methodology & Institutions & $\begin{array}{l}\text { Macro } \\
\text { approach }\end{array}$ & $\begin{array}{l}\text { Micro } \\
\text { approach }\end{array}$ & $\begin{array}{l}\text { Personal } \\
\text { conditions and } \\
\text { behaviour }\end{array}$ \\
\hline Top five & $-1.738^{*}$ & & $-1.053^{* * *}$ & $-0.838^{* * *}$ & $-0.431^{* *}$ \\
Other economics journals & $(1.027)$ & $(0.250)$ & $(0.214)$ & $(0.201)$ \\
& $(0.385)$ & -0.205 & $-0.559^{* *}$ & 0.196 \\
Constant & $-2.112^{* * *}$ & & $(0.284)$ & $(0.281)$ & $(0.253)$ \\
& $(0.182)$ & $0.535^{* * *}$ & $0.920^{* * *}$ & $0.843^{* * *}$ \\
Observations & 2518 & 2518 & $(0.0751)$ & $(0.0706)$ & $(0.0714)$ \\
\hline
\end{tabular}

Source: our own elaborations

Robust standard errors in parentheses, ${ }^{* * *} p<0.01, * * p<0.05, * p<0.1$. Journal base category (omitted): T-ec.hist

Table 3 Multinomial logit estimates: historical periods (2001-2018)

\begin{tabular}{llllll}
\hline Variables & $\begin{array}{l}\text { Classical and } \\
\text { medieval } \\
\text { (before 1492) }\end{array}$ & $\begin{array}{l}\text { Early Mod- } \\
\text { ern History } \\
(1492-1815)\end{array}$ & $\begin{array}{l}\text { Long nine- } \\
\text { teenth century } \\
(1815-1914)\end{array}$ & $\begin{array}{l}\text { Twentieth } \\
\text { century } \\
(1915 \text {-present) }\end{array}$ & Long-run \\
\hline Top five & 0.0371 & -0.194 & & $1.187 * * *$ & $1.529 * * *$ \\
Other economics journals & $(0.486)$ & $(0.295)$ & & $(0.191)$ & $(0.267)$ \\
& -0.0278 & $-0.672 *$ & & $0.990^{* * *}$ & $1.918^{* * *}$ \\
Constant & $(0.539)$ & $(0.379)$ & & $(0.211)$ & $(0.260)$ \\
& $-2.141^{* * *}$ & $-0.686^{* * *}$ & & $-0.228 * * *$ & $-1.947 * * *$ \\
Observations & $(0.107)$ & $(0.0598)$ & & $(0.0520)$ & $(0.0980)$
\end{tabular}

Source: our own elaborations

robust standard errors in parentheses, ${ }^{* * *} p<0.01$, $* * p<0.05, * p<0.1$. Journal base category (omitted): T-ec.hist

a quarter of them deal with the UK (almost half of the total for the $E H R$ ), especially looking at the Industrial Revolution. ${ }^{16}$

5.2 The database features a total of 2153 authors, with an average of 1.17 'contributions' each. ${ }^{17}$ At the time of publication, these authors were working in 595 universities and 115 other organisations (such as the World Bank, the Federal Reserve

\footnotetext{
16 As a robustness check, we ran the same set of regressions dropping from the database the European economic history journals ( $E H R, E R E H$ and $C L I O)$, thus, considering only the JEH and EEH. The coefficients for the USA (Table A6c in the Appendix) and advanced econometrics (Table A6d in the Appendix) are smaller but remain significant.

17 We assign to each author (and thus to his or her institution and, ultimately, to his or her country) the inverse of the number of authors of the article ( 0.5 if there are two authors, 0.33 if there are three and so on). We distinguish the fractionally weighted articles from the unweighted ones by using the word "contribution" instead of "article".
} 
Table 4 Multinomial logit estimates: geographical areas (2001-2018)

\begin{tabular}{|c|c|c|c|c|c|}
\hline Variables & Cross-country & Continental Europe & UK & USA & Rest of the world \\
\hline Top five & $\begin{array}{l}2.448 * * * \\
(0.443)\end{array}$ & $\begin{array}{l}1.497 * * * \\
(0.448)\end{array}$ & & $\begin{array}{l}2.827 * * * \\
(0.427)\end{array}$ & $\begin{array}{l}1.926 * * * \\
(0.461)\end{array}$ \\
\hline Other economics journals & $\begin{array}{l}1.655^{* * * *} \\
(0.280)\end{array}$ & $\begin{array}{l}0.121 \\
(0.315)\end{array}$ & & $\begin{array}{l}0.918^{* * * *} \\
(0.291)\end{array}$ & $\begin{array}{l}0.247 \\
(0.364)\end{array}$ \\
\hline Constant & $\begin{array}{l}-0.502^{* * *} \\
(0.0737)\end{array}$ & $\begin{array}{l}0.208 * * * \\
(0.0609)\end{array}$ & & $\begin{array}{l}-0.119 * \\
(0.0660)\end{array}$ & $\begin{array}{l}-0.499 * * * \\
(0.0736)\end{array}$ \\
\hline Observations & 2468 & 2468 & 2468 & 2468 & 2468 \\
\hline
\end{tabular}

Source: our own elaborations

robust standard errors in parentheses, ${ }^{*} * p<0.01$, $* * p<0.05, * p<0.1$. Journal base category (omitted): T-ec.hist

Table 5 Multinomial logit estimates: econometric techniques (2001-2018)

\begin{tabular}{|c|c|c|c|}
\hline Variables & No econometrics & Basic econometrics & Advanced econometrics \\
\hline Top five & & $\begin{array}{l}1.047 * * * \\
(0.292)\end{array}$ & $\begin{array}{l}3.041 * * * \\
(0.297)\end{array}$ \\
\hline Other economics journals & & $\begin{array}{l}0.373 \\
(0.239)\end{array}$ & $\begin{array}{l}2.132 * * * \\
(0.251)\end{array}$ \\
\hline Constant & & $\begin{array}{l}0.780 * * * \\
(0.0488)\end{array}$ & $\begin{array}{l}-1.105^{* * *} \\
(0.0810)\end{array}$ \\
\hline Observations & 2518 & 2518 & 2518 \\
\hline
\end{tabular}

Source: our own elaborations

robust standard errors in parentheses, $* * * p<0.01$, $* * p<0.05, * p<0.1$. Journal base category (omitted): T-ec.hist

Table 6 Share of contributions by area of affiliation (2001-2018)

\begin{tabular}{lllll}
\hline Area & T-ec.hist & Top five & $\begin{array}{l}\text { Other economics } \\
\text { journals }\end{array}$ & T8 \\
\hline Continental Europe & 31.5 & 12.7 & 21.6 & 16.8 \\
UK & 23.7 & 4.7 & 15.0 & 9.4 \\
USA & 32.0 & 78.8 & 53.1 & 67.0 \\
Other Anglo-Saxon countries & 7.1 & 1.9 & 6.0 & 3.8 \\
Rest of the world & 5.7 & 1.9 & 4.3 & 3.0 \\
Total & 100 & 100 & 100 & 100 \\
\hline
\end{tabular}

Source: our own elaborations

Board of Governors or the Federal Reserve Bank of New York). Almost all these institutions were located in Europe and in North America, but there is a striking difference between the balanced distribution of affiliations in economic history journals and the strong concentration in the USA in economics journals, especially in the top five (Table 6). 


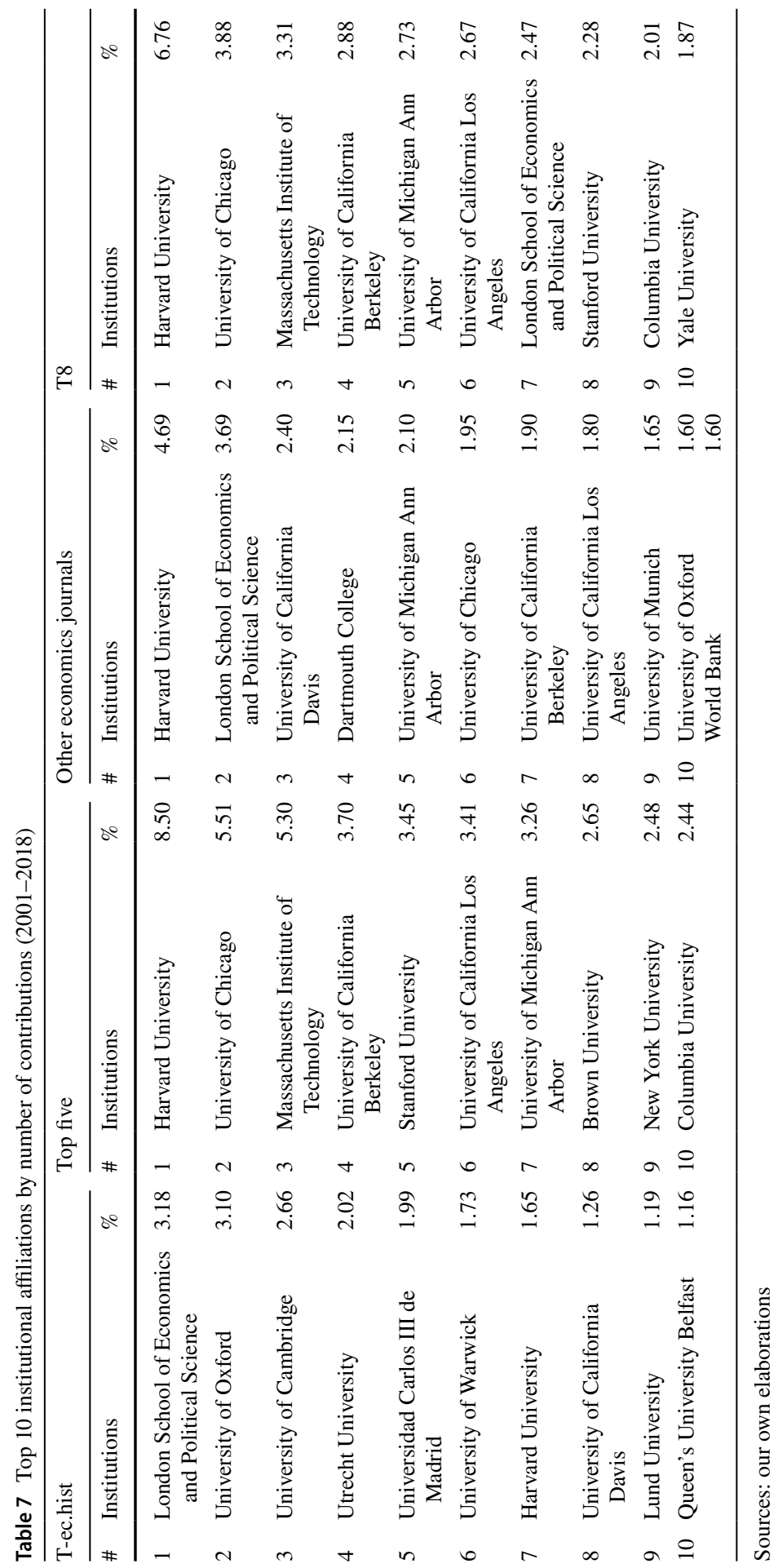


Two-thirds of the authors of economic history articles in the T8 and four-fifths in the top five were affiliated with American universities. In all likelihood, this concentration reflects the well-known 'tyranny' of the top five (Heckman and Moktan 2020). Publishing in economic history journals, as in all field journals, and even in the other major generalist journals (the 'other economics journals'), may not be enough to get tenure or promotion in top American universities (Margo 2018).

Unsurprisingly, the difference in location between economic history and economics is even greater if one considers the list of the top ten institutions (Table 7). Eight European universities (five British and three Continental) feature in the top ten for the T-ec.hist, one only in the top ten for the T8 and none for the top five. The highest ranked Continental European university in T8 (and in the top five), Universitat Pompeu Fabra, is only 13th overall. Furthermore, the London School of Economics, the top-ranked institution in the T-ec.hist and the only non-American institution in the T8, is a sui generis case. Almost all authors of articles in the T-ec.hist are affiliated with the Department of Economic History, while over three-quarters of all articles in the T8 were written by members of other departments (mostly Economics). Only one nonacademic organisation, the World Bank, appears in Table 7 at the 10th position of the ranking for the 'other economics journals', but it drops to the 32nd position in T8.

This difference in affiliations is arguably part of a more general cleavage between authors publishing in economics journals ('economists') and in economic history journals ('economic historians'), which we document in Fig. 3. We count the number of authors distinguishing the type of article ('traditional economic history' or 'persistence studies') and two sets of journals - the whole database on the left (Fig. 3a) and a reduced one, featuring only the top five and the T-ec.hist, on the right (Fig. 3b).

More than nine economic historians out of ten (92\%) have published only in the T-ec.hist, and almost seven economists out of ten $(69.1 \%)$ have published exclusively in the T8. Only 142 'hybrid' authors (6.6\% of the total of 2153 ) have published one article in both T-ec.hist and T8, and only 37 'high flyers' (1.7\% of the total) have authored (or co-authored) at least two articles in both groups of journals. On the other hand, the 142 'hybrid' authors were substantially more productive than both 'pure' economic historians and 'pure' economists. ${ }^{18}$ They account for more than one-sixth (17.2\%) of all contributions to the T-ec.hist and for exactly one-third $(33.7 \%)$ of all contributions to the T8. ${ }^{19}$ Figure 3 a also shows that the authors of 'persistence studies', or 'persistence economists', are a distinctive 'tribe' even among economists. More than half of them (37 out of 65) have published only 'persistence

\footnotetext{
18 Each "hybrid" author has published 0.9 contributions in the T8, with a median of 0.5 , while the 369 pure "economists" have published 0.6 contributions each, with the same median as the "hybrid" authors. Moreover, the "hybrid" authors have published 2.6 contributions each in T-ec.hist, with a median of 1.8, versus 1.1 contributions each and a median of 0.8 for the 1642 pure "economic historians".

19 By definition, the impact of the 37 "high-flyers" is proportionally larger: they account for $6.5 \%$ of contributions to the T-ec.hist journals and $15.3 \%$ to the T8.
} 
(a) T8 and T-ec.hist

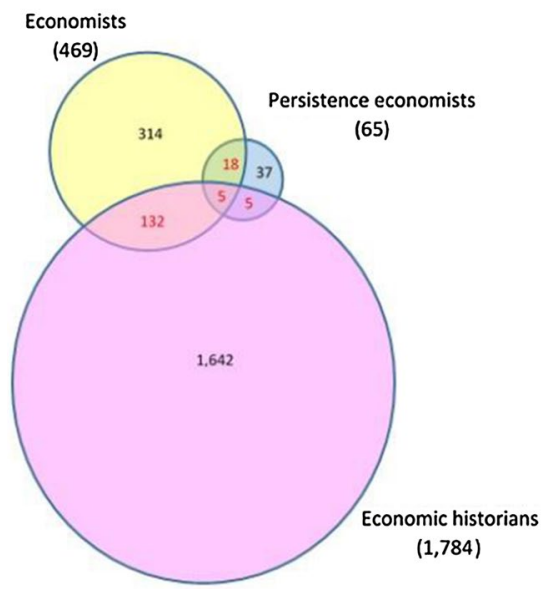

(b) Top five and T-ec.hist

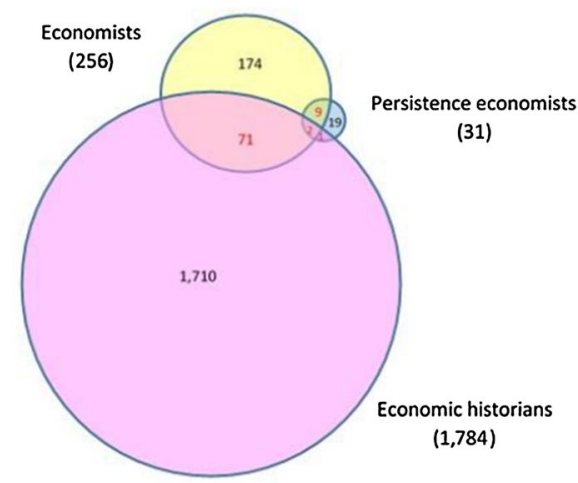

Fig. 3 The three tribes: size and relationships (2001-2018). Source: our own elaborations. Notes: circle size indicates the number of scholars in each group; the pink circle refers to scholars publishing in economic history journals; the yellow and blue circles refer to scholars publishing in economics journals (respectively, 'economists', those publishing 'traditional economic history' articles and 'persistent economists' those publishing 'persistence studies' articles)

studies', almost always with a co-author, and no other economic history articles (of course, they have been active in other fields of economics), while only five scholars have contributed to all three categories ('persistence studies', 'traditional economic history' and articles in the T-ec.hist). The number of 'hybrid' authors is, by definition, smaller if one takes into account only the top five (Fig. 3b). Only 74 people (3.4\% of the total in the database) have published in both a top-five journal and a T-ec.hist journal, and only $17(0.8 \%)$ of them are 'high-flyers'. However, 'hybrid' scholars account for $26.8 \%$ of authors in the top five (74 out of 276 ) and for $31.7 \%$ in the 'other economics journals' (90 out of 284).

It is well known that economics is a male-dominated field (Hamermesh 2013), and economic history is not an exception. Overall, in our database, women account for $19.2 \%$ of all authors, $17.1 \%$ of all 'pure' economists, $20 \%$ of all 'pure' economic historians and $14.8 \%$ of 'hybrid' authors. The share of women is somewhat higher $(23.7 \%)$ among the pure 'persistence economists', possibly because a new approach attracts more young scholars, among which women are better represented.

5.3. We explore the interaction between economics and economic history journals with four measures of the share of direct and cross-citations, defined, respectively, as citations to a journal in the same group (a T-ec.hist citing another T-ec. hist) and as citations to the other group. Table 8 reports the results separately for T-ec.hist and T8.

The first two rows measure the interest of economic historians and economists to engage in the scholarly debate. We proxy it with the share of articles that quote at least once (rows i) or at least three times (rows ii) articles published in T-ec. hist and in T8. First, economists are somewhat more interested in the work of their 
Table 8 Citation patterns by groups of journals

T-ec.hist

T-ec.hist

(i) \% Articles citing at least one article in

89.1

76.9

(ii) \% Articles citing at least three articles in

64.5

46.8

(iii) \% References to articles in the journals in the database

(iv) \% References on total references

T8

(i) \% Articles citing at least one article in

98.3

(ii) \% Articles citing at least three articles in

92.8

(iii) \% References to articles in the journals in the database

(iv) \% References on total references

Source: our own elaborations on data on references retrieved from Scopus between 13 and 18 May 2019

colleagues than economic historians. Almost all 365 articles in the T8 quote other articles in the T8 (98.3\% quote at least one article and $92.8 \%$ quote three or more), while the same shares for the $2153 \mathrm{~T}$-ec.hist articles are decidedly lower $(89.1 \%$ and $64.5 \%$, respectively). In contrast, economists are much less interested than economic historians in the scholarly debates in the other community. Three-quarters (76.9\%) of articles in T-ec.hist quote at least one article in T8, and almost half (46.8\%) quote at least three articles, while only half (53.5\%) of articles in T8 quote at least one article in T-ec.hist, and less than one-third (31.5\%) quote at least three articles.

The two other rows (iii and iv) of Table 8 measure the overall impact of economic history articles. They have the same numerator, the number of references to articles in T-ec.hist or T8, but a different denominator. In rows (iii), the denominators are the number of citations to the articles of the journals in the database, thus adding up, by definition, to $100 \%$, while the denominators of rows (iv) are the total number of citations, including those to other journals, books, original sources, etc. The difference between economic history and economics journals is again stark. The T8 quote other T8 frequently $81.3 \%$ of citations to journals in the database and $16.8 \%$ of all citations) and quote the T-ec.hist journals rather infrequently (the remaining $18.7 \%$ of references in the database and only $3.9 \%$ of all references). The T-ec.hist quote $\mathrm{T} 8$ more frequently (39.5\% of citations), although these account for merely $5.7 \%$ of all citations, mainly because economic history journals quote many other materials (books, sources, etc.). ${ }^{20}$ In summary, our data suggest that economists pay less attention to economic historians than they receive, as they do with other social sciences (Fourcade et al. 2015).

\footnotetext{
${ }^{20}$ On average, each article in economics journals cites 2.4 articles published in T-ec.hist and 10.4 in T8 (median values: 1 and 9), while an article in T-ec.hist cites 5.2 and 3.4 articles published, respectively in T-ec.hist and in T8 (median values: 4 and 2).
} 


\section{The success in citations}

The citation count became the standard gauge for measuring the impact of research in scientific fields long ago and is now commonly accepted in the social sciences and economics (Card and DellaVigna 2013; Hamermesh 2018). We measure success with the number of citations per year since publication because the passing of time yields more opportunities to be cited, ceteris paribus (Table 9).

Table 9 highlights two points. First, as expected, articles in field journals (here the T-ec.hist) are cited substantially less than articles in top economics journals. ${ }^{21}$ The differences with the top five are, as expected, quite large, but they remain substantial also with the 'other economics journals'. They range from a minimum of 2.6 times between the $E J$ and the $J E H$ to a maximum of 15.6 times for the JEL vs. CLIO. Second, 'persistence studies' are more successful than 'traditional economic history', and this cannot be mechanically related to the outlet. The top five have published $52 \%$ of all 'persistence studies' and 54\% of 'traditional economic history' articles. Furthermore, economic history articles in economics journals are cited more than the average of all other articles in the top five (11.1 vs. 5.4), although this is not true for the 'other economics journals' (an average of 5.6 for economic history articles and 6.7 for all the rest).

In theory, success might depend not only on the journal (T-ec.hist or T8) and/ or on the methodological approach ('traditional economic history' vs. 'persistence studies') but also on the topic, period and geographical area (cf. Section 5) or on other characteristics of the article (e.g. the number and the affiliation of the authors). We address this issue with a set of regressions, using the number of citations per year as the dependent variable (Table 10 and Table A8 in Appendix). ${ }^{22}$

In the simplest specification (Column 1), we measure the premium from publishing articles of economic history in any of the T8 relative to publishing in a field journal (T-ec.hist). ${ }^{23}$ Then, we distinguish between groups of economics journals (Column 2) or between types of articles (Column 3). Columns 4 to 6 reproduce the specifications of the first three columns, adding an extensive set of controls (see note to Table 10 for a detailed list). Finally, in Column 7, we contrast the relative importance of publication outlet and type of article as causes of citational success. ${ }^{24}$

\footnotetext{
21 For the list of the top 10 cited articles for the top five and T-ec.hist, see Table A7 in the Appendix.

22 All values are rounded up to the nearest higher integer to run a negative binomial model, which is the more suitable econometric approach when the distributions are highly skewed and display an excess of zero-valued observations. As a robustness check, we also carried out a similar set of Poisson regressions, obtaining fully consistent results in terms of the size and significance of the coefficients.

23 As a robustness check, we have considered the two American journals (EEH and $J E H$ ) as the base category instead of all five (Table A9 in the Appendix). The results are fully consistent with the specification used in the full sample. As a further robustness check on the selection process of articles, we rerun the regression using the database by Abramitzky (2015), who selected the economic history articles looking only at the JEL codes. The results for a comparable sample (top five in the years 2001-2014) are identical (see Table A10 in the Appendix). We thank Ran Abramitzky for having shared his data with us. 24 Including dummies for both 'traditional economic history' and 'persistence studies' would have caused multicollinearity. Thus, we prefer to focus on 'persistence studies', as they have collected more citations than 'traditional economic history' articles.
} 
Table 9 Average and median citations per year (2001-2018)

\begin{tabular}{|c|c|c|c|c|c|c|}
\hline \multirow[t]{2}{*}{ Journal } & \multicolumn{2}{|c|}{$\begin{array}{l}\text { Traditional economic } \\
\text { history }\end{array}$} & \multicolumn{2}{|c|}{ Persistence studies } & \multicolumn{2}{|l|}{ Total } \\
\hline & Average & Median & Average & Median & Average & Median \\
\hline CLIO & 1.0 & 0.7 & & & 1.0 & 0.7 \\
\hline EEH & 1.3 & 0.9 & & & 1.3 & 0.9 \\
\hline EHR & 1.6 & 1.1 & & & 1.6 & 1.1 \\
\hline EREH & 1.3 & 0.9 & & & 1.3 & 0.9 \\
\hline JEH & 1.6 & 1.2 & & & 1.6 & 1.2 \\
\hline T-ec.hist & 1.4 & 1.0 & & & 1.4 & 1.0 \\
\hline AER & 7.4 & 4.8 & 37.8 & 10.7 & 10.3 & 5.3 \\
\hline ECMA & 4.1 & 4.0 & 14.4 & 13.7 & 8.6 & 4.8 \\
\hline JPE & 6.2 & 4.4 & & & 6.2 & 4.4 \\
\hline QJE & 13.1 & 8.2 & 27.0 & 19.0 & 14.9 & 10.1 \\
\hline RESTUD & 12.2 & 7.6 & & & 12.2 & 7.6 \\
\hline Top five & 8.9 & 5.2 & 29.2 & 15.7 & 11.1 & 5.9 \\
\hline EJ & 4.1 & 2.6 & 4.5 & 2.6 & 4.1 & 2.6 \\
\hline JEL & 10.6 & 4.4 & 97.8 & 97.8 & 16.1 & 4.8 \\
\hline RESTAT & 4.8 & 2.8 & 6.3 & 4.0 & 5.0 & 3.0 \\
\hline Other economics journals & 5.1 & 3.0 & 10.3 & 4.0 & 5.6 & 3.1 \\
\hline T8 & 7.2 & 3.9 & 20.2 & 8.3 & 8.6 & 4.2 \\
\hline
\end{tabular}

Bold values indicates sub-total and total number of articles by group of journals

Source: our own elaborations on data on references retrieved from Scopus between 13 and 18 May 2019

The specifications show, as expected, that articles in the T8 receive more citations per year than those in the T-ec.hist (Column 1), articles in top five more than in 'other economics journals' (Column 2) and 'persistence studies' more than 'traditional economic history' articles (Column 3). After introducing our set of controls (Columns 4-7), all variables remain highly significant, but the coefficients are lower, especially for 'persistence studies'. However, the gaps with the T-ec.hist, as measured by marginal effects, are very large: 5.8 more citations per year for an article in the top five, 3.2 for one in the 'other economics journals', 4.8 for a 'traditional economic history' article, and up to 9.4 for a 'persistence studies'. Column 7 shows that the journal matters more than article type: the coefficients for the top five and 'other economics journals' remain almost the same, while the dummy for 'persistence studies' and the interaction term with the top five are both positive but not significant. This might appear to contrast with the substantially higher number of citations of 'persistence studies' (Table 9) than the 'traditional economic history' articles (let alone the articles in the T-ec.hist). Cioni, Federico and Vasta (2021b) argue that the success of 'persistence studies' depends on the very high number of citations garnered by three articles, the three most successful articles in their database, the seminal article already quoted by Acemoglu et al. (2001) on the colonial roots of underdevelopment, the survey by La Porta et al. (2008) on the economic 


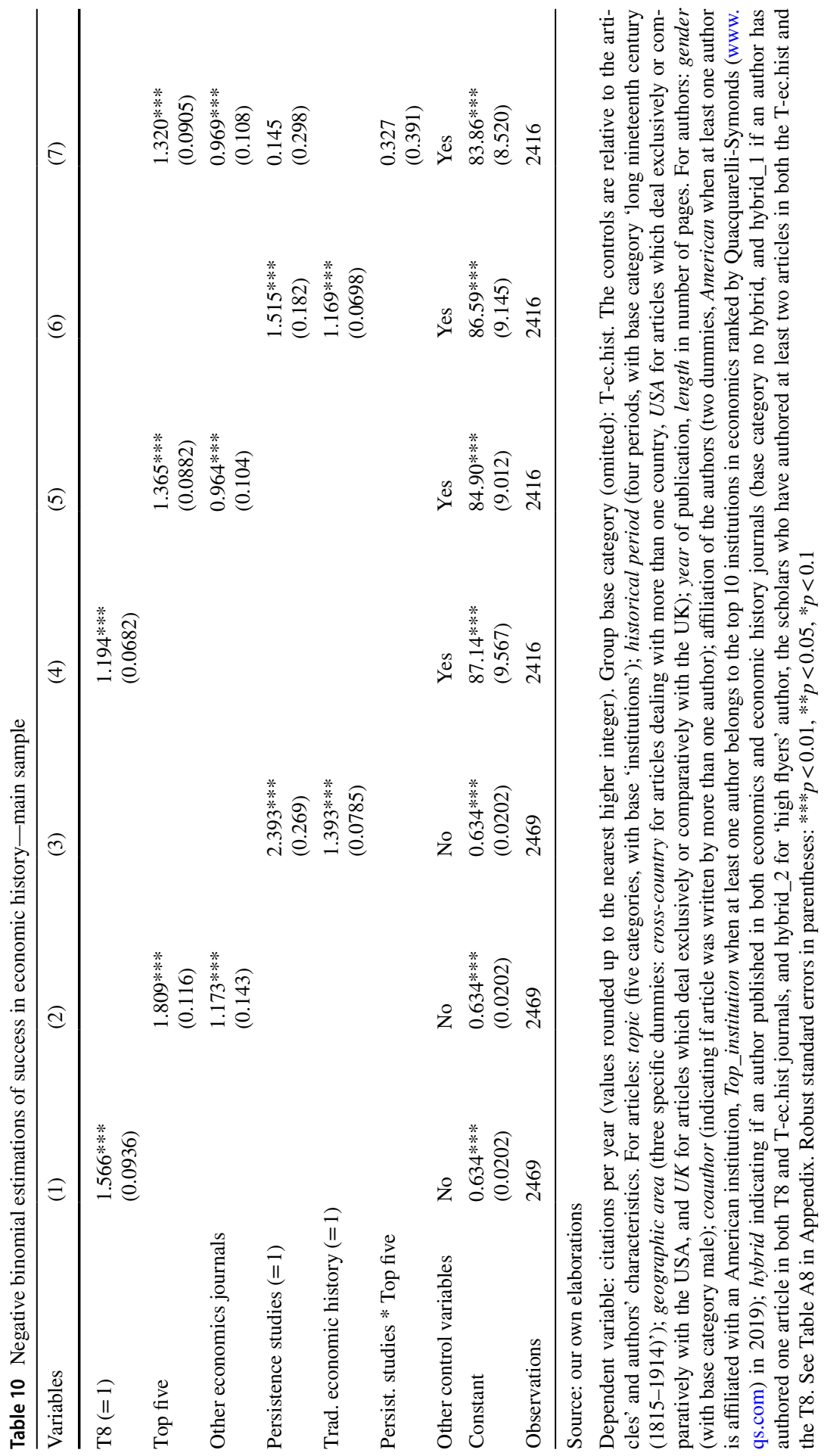


consequences of legal origins, and the article by Acemoglu, Johnson and Robinson on the reversal of fortune (2002). These articles have received 3688, 1443 and 1125 citations, or 199.4, 97.8 and 82.5 per year, respectively, and account for almost twothirds (65.4\%) of all citations of 'persistence studies'.

The controls to our baseline regression add some important insights about the causes of success (see Table A8 in Appendix). In the whole sample, the techniques used were not significant. Articles on the 'micro approach' receive fewer citations than those on 'institutions' or on any other issue. Likewise, articles on the 'long nineteenth century (1815-1914)', the reference category, are quoted less than any other period, except the pre-1492 ones, which is a small category with only 107 articles ( $4.2 \%$ of the total). The 'cross-country' articles attract many more citations than any individual country study, including the USA. As expected, the year of publication is negative and significant: more recent articles are less likely to be cited, even after normalisation. As in Card and DellaVigna (2013) and Laband (2013), we find that longer articles are cited more, likely because they offer more content. We control for a wide range of characteristics of the authors, and only a few affect the success of their work. 'Hybrid' authors and 'high flyers' ('hybrid_2' in Table A8 in Appendix) do not receive significantly more citations than others, possibly because publishing in the T-ec.hist reduces their total tally. Consistent with the results of Hamermesh (2018), the gender of the author does not matter: the dummies for both articles by all-women teams and articles by mixed-gender teams are not significant. The affiliation with a generic American institution does not matter, while the dummy for top universities in economics is positive (1.1 additional citations per year on average, as seen in Columns 4-7) and highly significant. ${ }^{25}$ Finally, as expected (Card and DellaVigna 2013; Hamermesh 2018), co-authorship increases the number of citations by $10.5 \% .^{26}$

One might argue that our approach is slightly unfair towards articles in the T-ec. hist. Indeed, we are comparing a very small number of economics journals, which also attract readers with articles on other issues, with approximately one-sixth of all international economic history journals, which are generally read only by field scholars. ${ }^{27}$ Indeed, the gap between the number of citations per year between T8 and T-ec.hist shrinks if we consider only the most quoted articles in the latter. The average and median (5.1 and 4.2, respectively) of the top decile articles in T-ec. hist are similar to the statistics for the 'other economics journals', although still far

\footnotetext{
25 The top universities in economics, as ranked by Quacquarelli-Symonds in 2019, are: Harvard University, Massachusetts Institute of Technology (MIT), Stanford University, University of California Berkeley (UCB), University of Chicago, the London School of Economics and Political Science (LSE), Princeton University, Yale University, University of Oxford and University of Cambridge. Note that seven of these universities are included also in the top ten by number of contributions in the T8 (Table 7).

26 The optimal number of authors from the point of view of citational success seems to be three. The average number of citations per year over the whole database rises from 1.9 for single-authored articles to 2.7 for articles with two authors and to 4.1 for articles with three authors but then declines slightly to 2.9 for articles with four or more authors.

27 Scimago (www.scimagojr.com) features 621 journals in the category of economics and econometrics. In contrast, we have identified 23 journals as economic history journals, out of which 6 deal with business history (Cioni et al. 2020).
} 


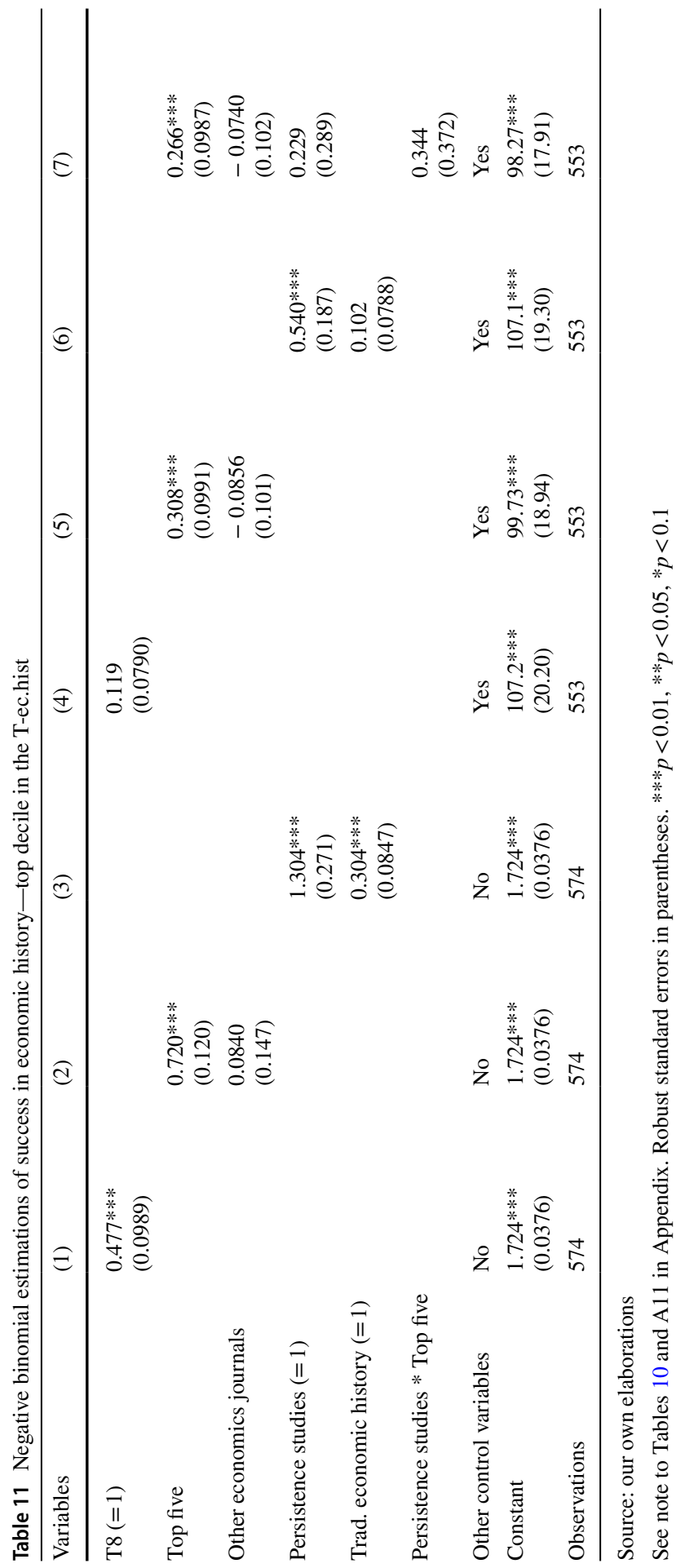


below those of the top five. The top decile of the T-ec.hist would sit at the middle of the distribution of all articles published in the T8. We test this hypothesis by re-running the regression limiting our sample to the articles in T-ec.hist in the top decile (Table 11 and full controls in Table A11 in Appendix). The dummies for journal group (Columns 1 and 2) and type of article (Column 3) remain positive and significant, but the coefficient is no longer significant for the 'other economics journals'. After adding the controls (Columns 4-6), the citation premium for publishing halves for the top five (from 5.8 citations per year to 2.4) and becomes negative, but not significant, for the 'other economics journals'. For the type of article, the citation premium halves for the 'persistence studies' (from 9.4 to 5.1) and becomes truly minimal for 'traditional economic history' articles (from 4.8 to 0.8). Finally, the results in Column 7 confirm that only articles of any type in the top five receive more citations than publications in the top decile of the T-ec.hist. Reassuringly, the change in sample hardly affects the coefficients of the controls. ${ }^{28}$

\section{Conclusions}

This paper has systematically investigated the 'integration of economic history into economics' through a quantitative analysis based on economic history articles published both in the top five field journals and in eight prominent general-interest economics journals. The results downplay the extent of the integration. There is no doubt that economists are more interested in economic history today than in the late twentieth century, but the impact of economic history in economics journals is still modest and has not been growing since 2001. Articles in economics and economic history journals differ quite substantially in topics, periods and geographical areas of interest, and the former use more advanced econometrics. Furthermore, economics journals pay significantly less attention to economic history journals than vice versa. The authors differ as well. Only a minority of them publish in both economics and economic history journals, while most can be classified as 'economists', 'persistence economists' or 'economic historians', who account for a small proportion of the worldwide community of scholars (almost ten thousand people, according to estimates by Baten and Mushallik (2012)). These three groups differ substantially in terms of their research questions, style of work, pattern of citations and, above all, affiliations. The 'economists' and 'persistence economists' are mainly affiliated with American universities, while two-thirds of the 'economic historians' are based in Europe.

Publishing in leading economics journals brings, ceteris paribus, more citations than publishing in field journals. On the other hand, it is well known that the competition to publish in those journals is fierce. Is the citational success of an economic history article in economics journals worth the effort? Our econometric analysis

\footnotetext{
${ }^{28}$ Even more reassuringly, the results are identical if, instead of the top decile, we take into account the top 365 articles by number of citations per year (the same number of articles in the T8) in the T-ec.hist (see Cioni et al. (2021c), Table A13 in the Appendix).
} 
suggests a nuanced answer. It is surely worth publishing any article in economic history in the top five economics journals. The 'tyranny' of the top five (Heckman and Moktan 2020) is, however, a common feature in all fields in economics, not just in economic history. Publishing in other major economics journals yields a smaller additional citation bonus relative to the top economic history journals, which disappears if the comparison is limited to the top decile of the distribution by citations per year of articles in economic history journals. In a nutshell, for truly good work in 'traditional economic history', the publication outlet matters only if the article is in the top five. 'Persistence studies' are intrinsically different, as they imply an unprecedented methodological shift.

The field is still evolving quickly, and thus, it is too early to assess the full impact of these new trends. It is unclear whether economic history as a whole will regain the status it enjoyed before World War Two and during the heyday of the Cliometrics Revolution and how it will evolve in the future. Will the success of persistence studies cause economic history to lose its soul and become a sub-field of development studies? Will persistence studies become a separate field? Or, perhaps, will a new synthesis (a 'merger not an acquisition' (Bisin and Federico 2021b)) develop, with scholars dealing with traditional and new research questions with a wide range of tools?

Supplementary Information The online version contains supplementary material available at https://doi. org/10.1007/s11698-022-00242-z.

Open Access This article is licensed under a Creative Commons Attribution 4.0 International License, which permits use, sharing, adaptation, distribution and reproduction in any medium or format, as long as you give appropriate credit to the original author(s) and the source, provide a link to the Creative Commons licence, and indicate if changes were made. The images or other third party material in this article are included in the article's Creative Commons licence, unless indicated otherwise in a credit line to the material. If material is not included in the article's Creative Commons licence and your intended use is not permitted by statutory regulation or exceeds the permitted use, you will need to obtain permission directly from the copyright holder. To view a copy of this licence, visit http://creativecommons.org/licen ses/by/4.0/.

\section{References}

Abramitzky R (2015) Economics and the modern economic historian. J Econ History 75(4):1240-1250

Acemoglu D, Johnson S, Robinson JA (2001) The colonial origins of comparative development: an empirical investigation. Am Econ Rev 91(5):1369-1401

Acemoglu D, Johnson S, Robinson JA (2002) Reversal of fortune: geography and institutions in the making of the modern world income distribution. Quart J Econ 117(4):1231-1294

Acemoglu D, Johnson S, Robinson JA (2012) The colonial origins of comparative development: an empirical investigation: reply. Am Econ Rev 102(6):3077-3110

Adena M, Enikolopov R, Petrova M, Santarosa V, Zhuravskaya E (2015) Radio and the rise of the Nazis in Prewar Germany. Quart J Econ 130(4):1885-1939

Albouy DY (2012) The colonial origins of comparative development: an empirical investigation: comment. Am Econ Rev 102(6):3059-3076

Alsan M (2015) The effect of the tsetse fly on african development. Am Econ Rev 105(1):382-410

Anauati V, Galiani S, Gàlvez RH (2016) Quantifying the life cycle of scholarly articles across fields of economic research. Econ Inq 54(2):1339-1355

Andreano R (1970) The new economic history: recent papers on methodology. Wiley, Oxford 
Angrist JD, Pischke JS (2010) The Credibility revolution in empirical economics: how better research design is taking the con out of econometrics. J Econ Persp 24(2):3-30

Angrist JD, Azoulay P, Ellison G, Hill R, Lu-Feng S (2020) Inside job or deep impact? Extramural citations and the influence of economic scholarship. J Econ Literature 58(1):3-52

Arroyo Abad L, Maurer N (2021) History never really says goodbye: a critical review of the persistence literature. J Historical Political Econ 1(1):31-68

Ashraf QH, Galor O (2018) The macrogenoeconomics of comparative development. J Econ Literature 56(3):1119-1155

Austin G (2008) The 'reversal of fortunes' thesis and the compression of history: perspectives from African and comparative economic history. J Int Dev 20(8):996-1027

Baten J, Muschallik J (2012) The global status of economic history. Econ History Dev Regions 27(1):93-113

Bisin A, Federico G (eds) (2021a) Handbook of historical economics. Academic Press, London

Bisin A, Federico G (2021) Merger or acquisition? An introduction to the handbook of historical economics. In: Bisin A, Federico G (eds) Handbook of historical economics. Academic Press, London

Bornmann L, Butz A, Wohlrabe K (2018) What are the top five journals in economics? A new metaranking. Appl Econ 50(6):659-675

Cantoni D, Yuchtman N (2021) Historical natural experiments: bridging economics and economic history. In: Bisin A, Federico G (eds) Handbook of historical economics. Academic Press, London, pp 213-242

Card DE, DellaVigna S (2013) nine facts about top journals in economics. J Econ Literature 51(1):144-161

Cioni M, Federico G, Vasta M (2020) The long-term evolution of economic history: evidence from the top five journals (1927-2017). Cliometrica 14(1):1-39

Cioni M, Federico G, Vasta M (2021a) The two revolutions in economic history. In: Bisin A, Federico G (eds) Handbook of historical economics. Elsevier Academic Press, London, pp 17-40

Cioni M, Federico G, Vasta M (2021b) Persistence studies: a new kind of economic history? University of Siena, Department of Economics and Statistics Working Papers n. 859

Cioni M, Federico G, Vasta M (2021c) The state of the art of economic history: the uneasy relation with economics. New York University Abu Dhabi, Division of Social Science Working Paper Series \#0067

Conrad AH, Meyer JR (1958) the economics of slavery in the ante bellum south. J Polit Econ 66(2):95-130

Debreu G (1991) The mathematization of economic theory. Am Econ Rev 81(1):1-7

Demeulemeester JL, Diebolt C (2007) How much could economics gain from history: the contribution of cliometrics. Cliometrica 1(1):7-17

Diebolt C, Haupert M. (2019b). The vital tools: how economic history complements and completes the training of an economist. presented at American Economic Association annual meeting

Diebolt C, Haupert M (2021) Cliometrics: Past, Present, and Future', BETA Bureau d'Économie Théorique et Appliquée Document de Travail n. 2021-13

Diebolt C, Haupert M (eds) (2019c) The Handbook of Cliometrics. Springer, Berlin and Heidelberg

Diebolt C, Haupert M (2019a) We are Ninjas: how economic history has infiltrated economics. Sartoniana 32:197-220

Dippell C, Leonard B (2021) Not-so-natural experiments in history. J Historical Polit Econ 1(1):1-30

Fourcade M, Ollion E, Algan Y (2015) The superiority of economists. J Econ Persp 29(1):89-114

Gerschenkron A (1962) Economic backwardness in historical perspective. Harvard University Press, Cambridge

Greasley D, Oxley L (2010) Clio and the economist: making historians count. J Econ Surv 24(5):755-774

Hamermesh DS (2013) Six decades of top economics publishing: who and how? J Econ Literature 51(1):162-172

Hamermesh DS (2018) Citations in economics: measurement, uses and impact. J Econ Literature 56(1):115-156

Heckman JJ, Moktan S (2020) Publishing and promotion in economics: the tyranny of the top five. J Econ Literature 58(2):419-470

Hilt E (2017) Economic history, historical analysis, and the "new history of capitalism. J Econ History 77(2):511-536

Jaremski M (2020) Today's economic history and tomorrow's scholars. Cliometrica 14(1):169-180

Kelly M (2019) The standard errors of persistence. CEPR Discussion Paper DP13783 
Kelly M (2020) Understanding Persistence. CEPR Discussion Paper DP15246.

La Porta R, Lopez-de-Silanes F, Shleifer A (2008) The economic consequences of legal origins. J Econ Literature 46(2):285-332

Laband DN (2013) On the use and abuse of economics journal rankings. Econ J 123(570):F223-F254

Lyons JS, Cain LP, Williamson SH (eds) (2007). Reflections on the cliometrics revolution. In: Conversations with economic historians. Routledge, London and New York

Margo R (2018) The integration of economic history into economics. Cliometrica 12(3):377-406

McCloskey D (1976) Does the past have useful economics? J Econ Literature 14(2):434-461

Michalopoulos S, Papaioannou E (2017) Series Introduction: Historical legacies and contemporary development. In: Michalopoulos S, Papaioannou E (eds) The long economic and political shadow of history, VoxEU.org Book III volumes. CEPR Press, London

Michalopoulos S, Papaioannou E (2020) Historical legacy and African development. J Econ Literature 58(1):53-128

Nunn N (2009) The importance of history for economic development. Ann Rev Econ 1:65-92

Nunn N (2020) The historical roots of economic development. Science 367:eaaz9986. https://doi.org/10. 1126/science.aaz 9986

Parker WN (ed) (1986) Economic history and the modern economist. Basil Blackwell, Oxford

Satyanath S, Voigtländer N, Voth HJ (2017) Bowling for fascism: social capital and the rise of the nazi party. J Polit Econ 125(2):478-526

Spolaore E, Wacziarg R (2013) How deep are the roots of economic development? J Econ Literature 51(2):325-369

Squicciarini MP, Voigtländer N (2015) Human capital and industrialization: evidence from the age of enlightenment. Quart J Econ 130(4):1825-1883

Sutch R (1991) All things reconsidered: the life-cycle perspective and the third task of economic history. J Econ History 51(2):271-288

Voth HJ (2021) Persistence: myth and mystery. In: Bisin A, Federico G (eds) Handbook of historical economics. Academic Press, London, pp 243-268

Wei G (2019) A bibliometric analysis of the top five economics journals during 2012-2016. J Econ Surv 33(1):25-59

Publisher's Note Springer Nature remains neutral with regard to jurisdictional claims in published maps and institutional affiliations. 